\title{
Diatom responses to river water quality in the Kruger National Park, South Africa
}

\author{
Authors \\ 1,2Purvance Shikwambana (1) \\ ${ }^{2}$ Jonathan C. Taylor (1) \\ 'Danny Govender (1) \\ 'Judith Botha (1)

\section{Affiliations Park, Skukuza, 1350. \\ ${ }^{2}$ North-West University, Unit for Environmental Sciences and Management, Private Bag X6001, NWU, Potchefstroom, 2520.} \\ ${ }^{1}$ Scientific Services, Kruger National
}

\section{Corresponding Author}

Prof. Jonathan Taylor Jonathan.Taylor@nwu.ac.za

\section{Dates}

Submitted: 30 September 2019 Accepted: 3 December 2020 Published: 24 February 2021

\section{How to cite this article:}

Shikwambana, P., Taylor, J.C., Govender, D. \& Botha, J., 2021, 'Diatom responses to river water quality in the Kruger National Park, South Africa', Bothalia 51(1), a5. http://dx.doi. org/10.38201/btha.abc.v51.i1.5

\begin{abstract}
Background: Although the Kruger National Park (KNP) is a protected area, it is not exempted from anthropogenically induced impacts, which often compromise river water flow and quality. Measures of river water quality in South Africa have conventionally been based on water chemistry as well as different ecological indicator groups such as fish and macroinvertebrates. Diatoms have been shown to be useful indicators of changes in water quality resulting from pollution and land-use impacts.
\end{abstract}

Objectives: To determine the applicability of diatoms for hind-casting water quality in the KNP and to compare recent diatom community composition with those from the 1980s.

Methods: In this study, $\mathrm{pH}$ and electrical conductivity (EC) were used to evaluate temporal changes in water quality of three rivers within the KNP. Additionally, we made use of historic diatom samples from three of the five perennial rivers to evaluate if diatom communities reflected changes in water conditions between 1983 and 2015.

Results: Diatom community structure was significantly different between 1983 and 2015. Diatom-based index scores (SPI) indicated an improvement in water quality for the Letaba and Olifants rivers.

Conclusion: Diatoms were shown to be useful indicators of current water quality and are also useful for determining temporal changes.

\section{Introduction}

Rivers are invaluable infrastructure globally. They are the main sources of available surface water in many countries including South Africa. Less than $0.3 \%$ of all the available surface water is freshwater (Griffiths et al. 2015). This portion of water is reported to be on a decline both in quality and quantity (Pillay \& Buckley 2001; Roux \& Nel 2012; Laine et al. 2014). Various freshwater taxonomic groups such as diatoms, macroinvertebrates and fish are commonly used to monitor freshwater water quality (Taylor et al. 2007a; Boix et al. 2010; Bere \& Mangadze 2014; Mangadze et al. 2016).

Five perennial rivers flow through the Kruger National Park (KNP) and although the KNP is a protected area, its rivers are not exempt from anthropogenically induced impacts that compromise water quality and flow (Dallas \& Day 2004; Pollard et al. 2011). As a result there has been a steady decline in water quality of most rivers in the KNP over time (Pollard \& du Toit 2011). The main anthropogenic activities impacting water quality are point source and diffuse pollution (Roux \& Nel 2012; Barnard et al. 2021). Sedimentation of river beds resulting from overgrazing, agriculture and sand-mining also impacts water quality and ecosystem health (Dallas \& Day 2004). River flow is mainly impacted by impoundment and abstraction (O'Keeffe \& Davies 1991; Riddell 
et al. 2013). Agricultural, urban and industrial activities are commonly sustained by water extracted from rivers - approximately $60 \%$ of river water supports agricultural activities, $24 \%$ goes to domestic use in urban areas and $3 \%$ of the water is used for industrial activities (DWA 2013). Water quality and quantity are crucial for sustainable freshwater ecosystems to benefit both livelihoods and the environment. Additionally, water quality is a key driver of productivity in aquatic systems - for instance if a system becomes moderately nutrient enriched, increased productivity may support several organisms depending on photosynthetic organisms. In some instances, when primary productivity is high (eutrophication), this may lead to problems such as algae blooms with associated toxic effects and trophic disruptions (Dallas \& Day 2004; Hart 2006, Tsu-Chuan \& Clark 2018; Zheng et al. 2019).

An ideal water quality monitoring tool needs to be simple, quick, repeatable and preferably use aquatic organisms that are not seasonal and habitat dependent (Round 1991; De la Rey et al. 2004, Harding et al. 2005). Measures of river water quality in South Africa have conventionally been based on water chemistry as well as taxonomically different ecological indicator groups, such as fish and macroinvertebrates (De la Rey et al. 2004; Harding et al. 2004; Wepener 2008). However, water chemistry measurements are often expensive and only measure absolute values of a limited number of variables on the day of sampling (de la Rey et al. 2004), meaning that some water quality disturbances may be missed. Biotic responders, such as macroinvertebrates, can also be limiting because they have different life stages often linked to seasons (Round 1991) and their distribution is usually variable due to habitat and flow conditions (De la Rey et al. 2004). Other concerns are that they were developed for specific types of streams, usually wade-able, low flow streams, meaning they cannot be monitored during the high flow season (Bate et al. 2004; Harding et al. 2005).

Unlike other taxonomic groups regularly used for biomonitoring, diatoms are less dependent on seasons (no larval stages), flow and habitat (Round 1991; De la Rey et al. 2004). Diatoms are in the Class Bacillariophyceae and are unique among algae as they have a cell wall composed of amorphous biogenic silica. Diatoms are photosynthetic, reproduce rapidly and may be attached or locally motile. Diatoms form thick biofilms in South Africa during the winter months and are major contributors to primary production. Diatoms are extremely useful ecological indicators (De la Rey 2004; Bate et al. 2004; Harding et al. 2005; Harding \& Taylor 2014; Mangadze et al. 2015; Dalu \& Froneman 2016). Additionally, diatoms are not geographically limited and their distribution is chiefly driven by water quality. Furthermore, diatoms' short life span and fast reproduction (Rott 1991) allow them to respond rapidly when water quality changes. The siliceous cell walls do not easily deteriorate after sampling, which allows for long-term storage and analysis of specimens (Harding \& Taylor 2011). Thus, diatoms have the potential to augment the current water quality monitoring methods.

In the past three decades (1983 to 2015), the KNP substantially influenced water management practices outside of the park. Adaptive management was implemented by KNP and external stakeholders, allowing real-time monitoring data to inform dam management and releases (Venter \& Deacon 1995; McLoughlin et al. 2011; Pollard et al. 2011). Some of the management strategies implemented includes the new water act, compulsory licencing and formation of catchment management agencies to provide local monitoring, enforcement and water licencing. On closing the adaptive management loop, the real-time responses worked much better with flow, a more complicated but tractable system responder than quality, a more sluggish and complex system responder (McLoughlin et al. 2011; Pollard et al. 2011; Riddell et al. 2013). This ultimately led to all rivers flowing during the 2015-2017 drought, one of the most severe droughts recorded, both in terms of MAR (mean annual rainfall) and average temperatures (Swemmer et al. 2018). Maintaining river flow generally means increased dilution capacity and therefore improvement in water quality, which in the case of the present study would be reflected by diatoms.

In the present study we investigated river eco-status of three perennial rivers of the KNP to evaluate if diatom communities changed when river eco-status changed. This is a necessary step towards integrating diatoms into river eco-status monitoring programmes as a possible diagnostic tool for assessing water quality in future, specifically in the KNP. Additionally, we made use of water quality data to evaluate change in all major KNP rivers from 1983 to 2015 . We used $\mathrm{pH}$ and EC to evaluate changes in water conditions at our sample sites because both variables were consistently collected. We then evaluated the potential of diatoms as water quality indicators by studying changes in diatom community structure in relation to $\mathrm{EC}$ and $\mathrm{pH}$. We specifically made use of a customised version of the Specific Pollution sensitivity Index (SPI), also referred to as the South African Diatom Index (SADI).

\section{Materials and Methods}

\section{Study area}

The study was conducted in three perennial rivers, the Letaba, Olifants and Sabie rivers (Figure 1), flowing through the semi-arid region of the Kruger National Park (KNP), South Africa. This part of the KNP receives approximately $537 \mathrm{~mm}$ average annual rainfall. The perennial rivers experience variable seasonal flow regimes and 


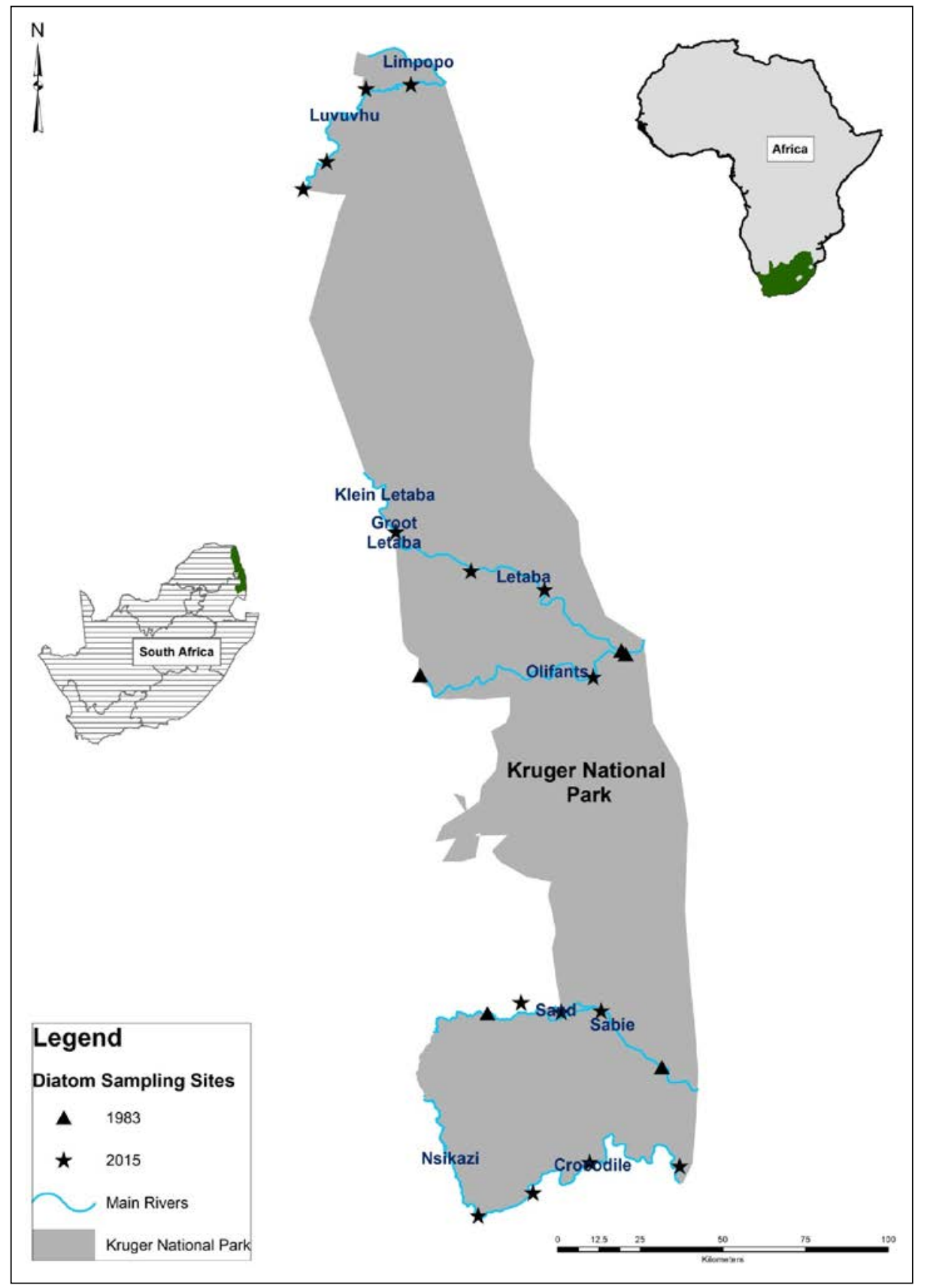

Figure 1. A map of the Kruger $\mathrm{Na}$ tional Park, showing the location of the study area and diatom sampling sites.

are influenced by large infrequent disturbances such as floods and droughts (O'Keefee \& Rogers 2003). The Olifants, Letaba and Sabie rivers have different catchment sizes and origins. The Olifants originates in the Highveld, far from the KNP. The Letaba and Sabie river originate close to the KNP and flow over similar geology (O'Keefee \& Rogers 2003). Land-use activities along the Olifants catchment are mainly mining, agriculture and forestry. However, land-use activities along the Letaba and Sabie rivers include agriculture and forestry. The catchment length for the Olifants, Letaba and Sabie are $840 \mathrm{~km}$, $573 \mathrm{~km}$ and $189 \mathrm{~km}$ respectively. A relatively long stretch of the Olifants and Letaba rivers are outside the KNP, accounting for $89 \%$ and $82 \%$ river length respectively. The Sabie River has only $37 \%$ of the river length outside the KNP (O'Keefee \& Rogers 2003; Pollard et al. 2011). The present study compared samples collected in September 2015 to historical samples collected in March 1983, river flow is often stable in both months. The average rainfall for March 1983 was $1.39 \mathrm{~mm}$ and $1 \mathrm{~mm}$ for September 2015 (SANParks data).

\section{Data collection}

\section{Diatoms}

Diatom samples were collected in 2015 in the KNP by SANParks staff members. No chordates or vertebrates were collected during the study. All historic diatom samples used in this study are part of the South African National Diatom Collection (SANDC) housed at the 
North-West University in Potchefstroom. These samples were collected in March 1983, using a similar sampling and slide preparation techniques as those used in the present study. Diatom samples collected in September 2015 followed the collection, preservation, preparation and analysis protocols as described in Taylor et al. (2007b). Briefly, five to ten average sized rocks (15 to $30 \mathrm{~cm}$ ) were randomly selected. The selected rocks were located at least a meter away from the river bank in the flowing part of the river, to avoid isolated waters and eddies. The surface of the rocks was scrubbed with a small brush and the resulting suspension preserved with ethanol (> 20\% final concentration). Samples were allowed to settle for 24 hours and then processed using the hot acid and $\mathrm{KMnO}_{4}$ method (Taylor et al. 2007b). Slides were mounted in Pleurax (Taylor et al. 2007b). Diatoms were viewed using an Olympus BX41 light microscope and identified according to Taylor et al. (2007a).

\section{Water quality}

Physicochemical parameters measured in situ during 2015 included $\mathrm{pH}$ and $\mathrm{EC}(\mu \mathrm{S} / \mathrm{cm})$. Measurements were recorded from active channels of the river before diatom samples were collected. A WTW LF95 (WeiIheim, Germany) handheld water quality meter was used to measure EC and a Cyberscan pH 300 meter (Eutech Instruments) to measure $\mathrm{pH}$. Unlike the diatom samples, historic physicochemical measurements included each year and all major rivers from 1983 to 2015. These historic physicochemical measurements were collated from the Department of Water and Sanitation official website (http://www.dwaf.gov.za/iwqs/ wms/data/accessed 06/07/2018).

\section{Data analysis}

OMNIDIA ver. 5.3 diatom interpretative software was primarily used to generate index scores using the counted and identified cells (Lecointe et al. 1993). A value between 1 and 20 was allocated to each sample based on species sensitivity values (Lecointe et al. 1993; Harding \& Taylor 2011) and then translated to an ecological class as shown in Table 1. The top five dominant species per river for the time periods were considered to elucidate drivers to specific water quality changes. Student t-tests were used to assess physicochemical parameters over time and their relationship to SPI score. An ANOSIM was also performed to test whether there were significant differences in diatom species similarity between years and a two dimensional multi-dimensional scaling (MDS) approach was used to visualise the similarity between sites using Primer 5 ver. 5.2.3 (Clarke \& Warwick 2001)

\section{Results}

\section{Changes in water quality indicators in the three studied rivers}

The $\mathrm{pH}$ and EC varied considerably $\mathrm{pH}$ : 6.3-8.9 and EC: 9.22-205.08) over time in all three studied rivers (Figure $2)$. The $\mathrm{pH}$ remained relatively similar $(\mathrm{p}>0.05)$ in the Olifants River over time, however for EC, there were significant differences ( $P=0.0013$ ) between 1983 and 2015 (Table 2). From additional historical data we also observed a steady decline in EC until early 2000, but it then stabilised at less than $90 \mu \mathrm{S} / \mathrm{m}$ from early 2000 to 2015 (Figure 2D). The Letaba River maintained an alkaline water column throughout 1983 to 2015. The EC was also generally maintained below $140 \mu \mathrm{S} / \mathrm{m}$. The Sabie River reflected a more neutral water column from the early 1980 s to an alkaline level in 2015. The Sabie River became more alkaline over time, with a significantly high $\mathrm{pH}$ in 2015 compared to $1983(\mathrm{P}=0.0004)$. Although the EC was quite low during the study period $(<50 \mu \mathrm{S} / \mathrm{m})$, it doubled between 1983 and $2015(P=0.0001)$.

\section{Diatom communities in 1983 and 2015}

A two dimensional multi-dimensional scaling approach was used to visualise the similarity between sights and shows two different clusters, namely the 1983 and 2015 sites, indicating change over time (Figure 3). An ANOSIM was also performed to test whether there are significant differences in diatom species similarity between years $(P=0.2)$ and the $R$ statistic of 0.587 . Even though the $\mathrm{p}$-value does not indicate a significant difference as the $\mathrm{R}$ value is closer to 1 , it indicates that there are greater differences between the years than within the years. The MDS indicates two distinct year groups so the insignificant $p$-value obtained in the ANOSIM may

Table 1. Ecological Class values for diatom indices (Eloranta \& Soininen 2002)

\begin{tabular}{llll}
\hline Ecological Class & Class & Trophy & Index Score (SPI/SADI) \\
\hline A & High quality & Oligotrophic & $>17$ \\
B & Good quality & Oligo-mesotrophic & $15-17$ \\
C & Moderate Quality & Mesotrophic & $12-15$ \\
D & Poor quality & Meso-eutrophic & $9-12$ \\
E & Bad quality & Eutrophic & $<9$ \\
\hline
\end{tabular}




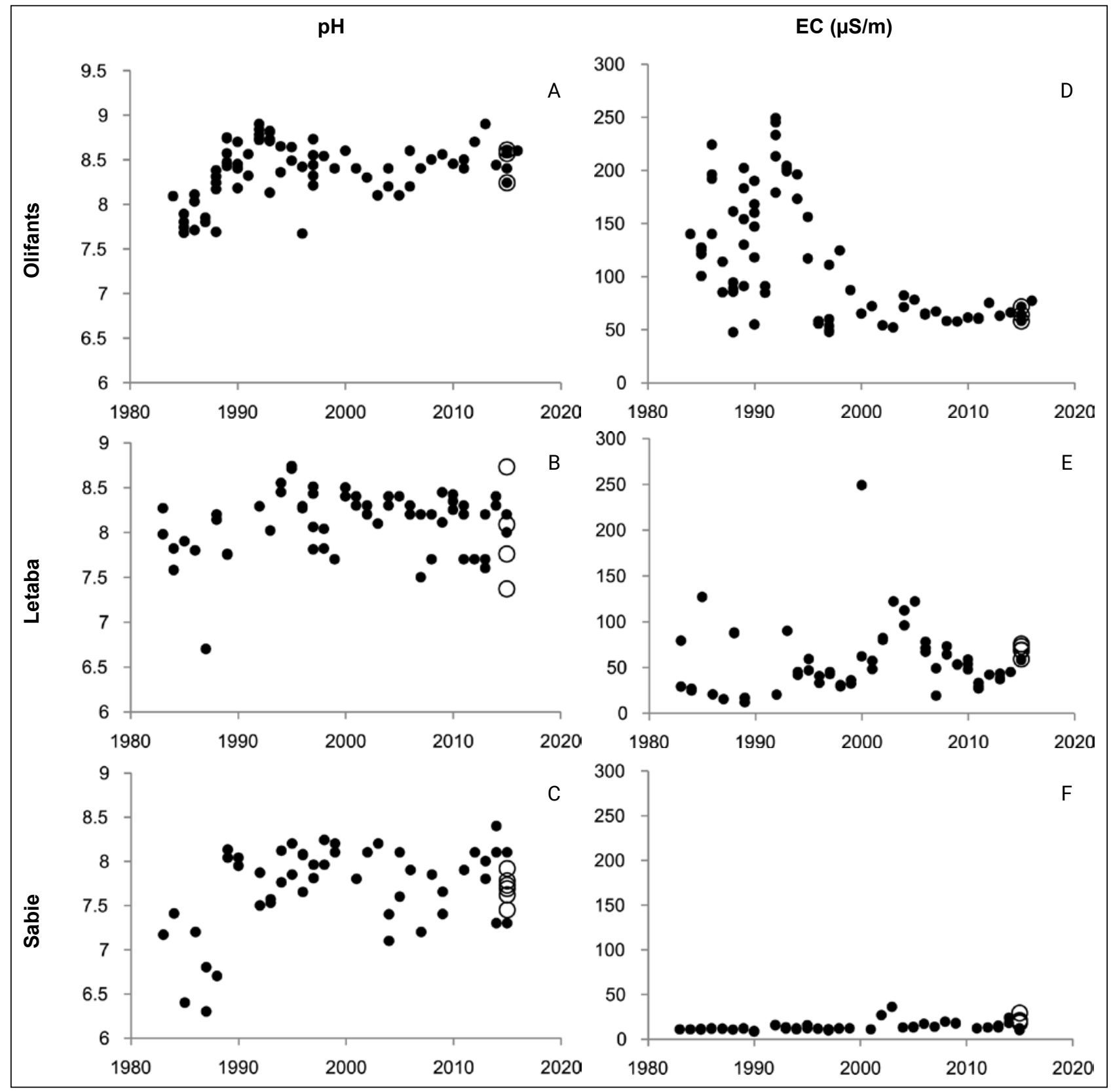

Figure 2. Long-term changes in two selected river chemical parameters in the Olifants, Letaba and Sabie rivers between 1983 and 2015. The closed symbols represent data extracted from the Department of Water Affairs and Sanitation. Open symbols represent the values recorded at sites within the three focal rivers during the present study in 2015.

be attributed to the small sample size and large number of different species collected.

\section{The top five dominant diatom species in 1983 and 2015}

The top five dominant diatom species at each site in 1983 and 2015 were compared in a table format (Table 4). Diatom species with more than $50 \%$ count were considered to be dominant. Nitzschia frustulum was dominant along the Olifants River in 1983. However, Rhoicosphenia abbreviata and Epithemia sorex became the two dominant species at $69.5 \%$ and $52.5 \%$ dominance respectively by 2015 . Rhopalodia gibba dominated the
Letaba River in 1983, but it decreased from $65.6 \%$ to $4 \%$ dominance in 2015, whilst Gomphonema parvulum reflected $66.5 \%$ dominance in the same year. The Sabie River was dominated by Cymbella kolbei. However, C. kolbei decreased from $79.5 \%$ dominance in 1983 to $5.25 \%$ dominance in 2015. Encyonopsis leei was the dominant species in 2015 for the Sabie River.

\section{The SPI index association with two water quality variables}

Both Olifants and Letaba rivers were eutrophic (Table 1) in 1983, reflected by a low SPI score of 7.4 and 7.1 respectively (Table 3 ). However, both rivers improved 
Table 2. Mean $\mathrm{pH}$ and EC $(\mu \mathrm{S} / \mathrm{m})$ values in 1983 and 2015 across the three rivers. Values in brackets represent $95 \%$ confidence limits. We also provide the sample size as well as the results of t-tests comparing 1983 and 2015. Shaded blocks highlight significant differences

\begin{tabular}{lllllll}
\hline River & $\mathbf{p H}$ & & $\mathbf{E C}(\boldsymbol{\mathbf { S }} / \mathbf{m})$ & & \\
& $\mathbf{1 9 8 3}$ & $\mathbf{2 0 1 5}$ & $\mathbf{t}$-test & $\mathbf{1 9 8 3}$ & $\mathbf{2 0 1 5}$ & $\mathbf{t}$-test \\
\hline Olifants & 8.14 & 8.49 & $\mathrm{t}=3.89$ & 149 & 66.3 & $\mathrm{t}=6.44$ \\
& $(8.03-8.25)$ & $(8.15-8.83)$ & $\mathrm{df}=3$ & $(94.87-205.08)$ & $(53.64-78.95)$ & $\mathrm{df}=5$ \\
& $\mathrm{n}=5$ & $\mathrm{n}=4$ & $\mathrm{p}=0.03$ & $\mathrm{n}=5$ & $\mathrm{n}=4$ & $\mathrm{p}=0.001$ \\
Letaba & 7.80 & 7.87 & $\mathrm{t}=0.25$ & 40.35 & 69.93 & $\mathrm{t}=2.2$ \\
& $(6.77-8.82)$ & $(7.15-8.5)$ & $\mathrm{df}=4$ & $(11.96-92.67)$ & $(60.60-79.26)$ & $\mathrm{df}=3$ \\
& $\mathrm{n}=4$ & $\mathrm{n}=9$ & $\mathrm{p}=0.115$ & $\mathrm{n}=4$ & $\mathrm{n}=9$ & $\mathrm{p}=0.8$ \\
Sabie & 7.16 & 7.69 & $\mathrm{t}=8.25$ & 11.60 & 21.25 & $\mathrm{t}=5.34$ \\
& $(7.12-7.38)$ & $(7.38-8.00)$ & $\mathrm{df}=6$ & $(9.22-13.97)$ & $(13.25-29.25)$ & $\mathrm{df}=6$ \\
& $\mathrm{n}=3$ & $\mathrm{n}=6$ & $\mathrm{p}<0.001$ & $\mathrm{n}=3$ & $\mathrm{n}=6$ & $\mathrm{p}=0.001$ \\
\hline
\end{tabular}

in SPI score in 2015. Olifants doubled its SPI score to 14.8 and Letaba increased to 10.4. The Sabie River reflected oligotrophic (Table 1) water quality for both 1983 and 2015. SPI score was 18.9 and 18.8 (Table 3). There was an association between SPI score and EC. However, there was no relation between SPI score and $\mathrm{pH}$ (Figure 4). Rivers with large catchments outside a protected area are exposed to various land use practices that compromise the rivers' water quality.

\section{Discussion}

Diatom based observations reflected a general change in diatom species composition over time. A change in diatom species composition suggests that there has

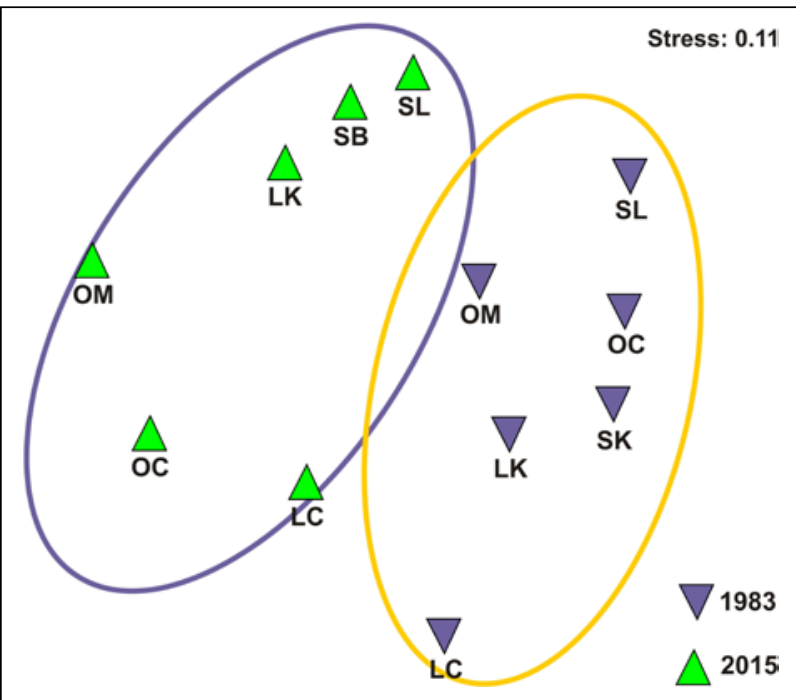

Figure 3. Two-dimension MDS plot of diatom community composition in 1983 and 2015 at different sites along the Olifants (OM and OC), Letaba (LC and LK) and Sabie rivers (SL and SB). Note that all sites' diatom composition shifted significantly from 1983 to 2015 irrespective of whether the index values changed or not (see Table 4). Sample site abbreviations also in Table 4. been a change in water quality along the Olifants, Letaba and Sabie rivers between 1983 and 2015 (Figure 3). Both the Olifants and Letaba rivers improved in water quality as was reflected by the diatom index (SPI score). However, the Sabie River did not show any significant change in water quality in relation to SPI scores.

O'Keeffe \& Rogers (2003) suggest that the Sabie and Letaba rivers should have similar water quality considering the geology of their catchments. However, rivers are complex systems influenced by many aspects other than the geology (Stevenson \& Pan 1999). The Letaba River has a significant proportion of its catchment outside the KNP. However, a significant proportion of the Sabie River catchment is within the KNP (Pollard et al. 2011), hence the Sabie River is considered the least modified river in the KNP, while the Letaba River is modified and impacted by impoundments and other anthropogenic activities (O'Keeffe \& Rogers 2003). Impoundments often have severe consequences for water quality including dissolved oxygen reduction, increased carbon dioxide and increased EC (Dallas \& Day 2004). Over and above the dams outside the KNP, the Letaba River has two impoundments located within the KNP, the Mingerhout and Engelhardt dams. These impoundments coupled with agricultural runoff and urban runoff (Dalu et al. 2015; Mangadze et al. 2017) could be compromising water quality in the Letaba River. However,

Table 3. Summary of river ecological class, SPI value and water quality status comparison of the Olifants, Letaba and Sabie rivers using diatom based observations for 1983 and 2015

\begin{tabular}{|c|c|c|c|}
\hline River & 1983 & 2015 & Trophy \\
\hline Olifants & $\begin{array}{l}\text { SPI }=7.4 \\
\text { Eutrophic }\end{array}$ & $\begin{array}{l}\text { SPI }=14.8 \\
\text { Meso-eutrophic }\end{array}$ & $\begin{array}{l}\text { Meso- } \\
\text { eutrophic }\end{array}$ \\
\hline Letaba & $\begin{array}{l}\text { SPI }=7.1 \\
\text { Eutrophic }\end{array}$ & $\begin{array}{l}\text { SPI }=10.4 \\
\text { Meso-eutrophic }\end{array}$ & $\begin{array}{l}\text { Meso- } \\
\text { eutrophic }\end{array}$ \\
\hline Sabie & $\begin{array}{l}\text { SPI }=18.9 \\
\text { Oligotrophic }\end{array}$ & $\begin{array}{l}\text { SPI }=18.8 \\
\text { Oligotrophic }\end{array}$ & Oligotrophic \\
\hline
\end{tabular}


Table 4. Comparison of top five dominant diatom species at each site in 1983 and 2015. Note that some diatom species with more than $50 \%$ (bold) dominance in 1983 were no longer dominant in 2015. In 2015 some of the dominant species were replaced by other species with more than $50 \%$ (bold) dominance

\begin{tabular}{|c|c|c|c|c|c|c|}
\hline 1983 & & & & 2015 & & \\
\hline Site name & Species name & Count & $\%$ & Species name & Count & $\%$ \\
\hline \multirow{5}{*}{$\begin{array}{l}\text { Olifants River } \\
(\mathrm{OM})\end{array}$} & Nitzschia frustulum & 188 & 47 & Rhoicosphenia abbreviata & 278 & 69.5 \\
\hline & Navicula cryptotenelloides & 84 & 21 & Cocconeis pediculus & 59 & 14.75 \\
\hline & Gomphonema parvulum & 81 & 20.25 & Nitzschia frustulum & 41 & 10.25 \\
\hline & Seminavis strigosa & 21 & 5.25 & Cocconeis placentula & 19 & 4.75 \\
\hline & Nitzschia kurzii & 7 & 1.75 & Gomphonema pseudoaugur & 3 & 0.75 \\
\hline \multirow{5}{*}{$\begin{array}{l}\text { Olifants River } \\
\text { (OC) }\end{array}$} & Nitzschia frustulum & 266 & 66.5 & Epithemia sorex & 210 & 52.5 \\
\hline & Cyclotella meneghiniana & 63 & 15.75 & Cocconeis placentula & 159 & 39.75 \\
\hline & Navicula cryptotenelloides & 26 & 6.5 & Rhoicosphenia abbreviata & 13 & 3.25 \\
\hline & Gomphonema parvulum & 13 & 3.25 & Nitzschia elegantula & 8 & 2 \\
\hline & Eolimna subminuscula & 9 & 2.25 & Rhopalodia gibba & 5 & 1.25 \\
\hline \multirow{5}{*}{$\begin{array}{l}\text { Letaba River } \\
\text { (LK) }\end{array}$} & Pseudostaurosira brevistriata & 112 & 28 & Gomphonema parvulum & 91 & 22.75 \\
\hline & Nitzschia palea & 101 & 25.25 & Nitzschia frustulum & 76 & 19 \\
\hline & Nitzschia frustulum & 34 & 8.5 & Nitzschia paleacea & 45 & 11.25 \\
\hline & Navicula symmetrica & 28 & 7 & Bacillaria paradoxa & 45 & 11.25 \\
\hline & Nitzschia umbonata & 27 & 6.75 & Amphora strigosa & 38 & 9.5 \\
\hline \multirow{5}{*}{$\begin{array}{l}\text { Letaba River } \\
\text { (LC) }\end{array}$} & Rhopalodia gibba & 67 & 65.699 & Cocconeis placentula & 266 & 66.5 \\
\hline & Navicula symmetrica & 13 & .80 & Nitzschia palea & 25 & 6.25 \\
\hline & Navicula cryptotenelloides & 5 & 12.75 & Nitzschia communis & 24 & 6 \\
\hline & Rhopalodia gibberula & 4 & 4.90 & Epithemia sorex & 22 & 5.5 \\
\hline & Fallacia umpatica & 3 & 3.92 & Rhopalodia gibba & 16 & 4 \\
\hline \multirow{5}{*}{$\begin{array}{l}\text { Sabie River } \\
\text { (SB) }\end{array}$} & Cymbella kolbei & 318 & 79.50 & Encyonopsis leei & 215 & 53.75 \\
\hline & Navicula rhynchocephala & 31 & 7.75 & Gomphonema gracile & 35 & 8.75 \\
\hline & Navicula frustulum & 15 & 3.75 & Achnanthidium affine & 33 & 8.25 \\
\hline & Gomphonema parvulum & 7 & 1.75 & Navicula zanoni & 26 & 6.5 \\
\hline & Planothidium rostratum & 5 & 1.25 & Cymbella kolbei & 21 & 5.25 \\
\hline \multirow{5}{*}{$\begin{array}{l}\text { Sabie River } \\
\text { (SL) }\end{array}$} & Planothidium rostratum & 199 & 49.75 & Encyonema leei & 168 & 42 \\
\hline & Staurosira elliptica & 59 & 14.75 & Gomphonema parvulum & 54 & 13.5 \\
\hline & Anorthoneis dulcis & 26 & 6.50 & Cymbella turgida & 44 & 11 \\
\hline & Navicula symmetrica & 25 & 6.25 & Navicymbula pusilla & 43 & 10.75 \\
\hline & Navicula frustulum & 25 & 6.25 & Sellaphora pupula & 20 & 5 \\
\hline
\end{tabular}

all impoundments on the Sabie catchment are located outside the KNP. Although the Sabie River is considered to be the least modified of the two, our study has reflected significant changes in both $\mathrm{EC}$ and $\mathrm{pH}$ between 1983 and 2015. At the same time, there was a shift in diatom community structure between 1983 and 2015 (Figure 3), although there was no significant change in SPI score (Table 3).
The Letaba River experienced periodic lentification from the 1960s to mid-1990s due to impoundments for agriculture (O'Keeffe \& Uys 1998; Pollard et al. 2011). However, flow was restored after negotiations between KNP freshwater management and catchment managers (O'Keeffe \& Rogers 2003). We would expect dissolved salts to be more concentrated during this period, resulting from low flows and sometimes lentification and 


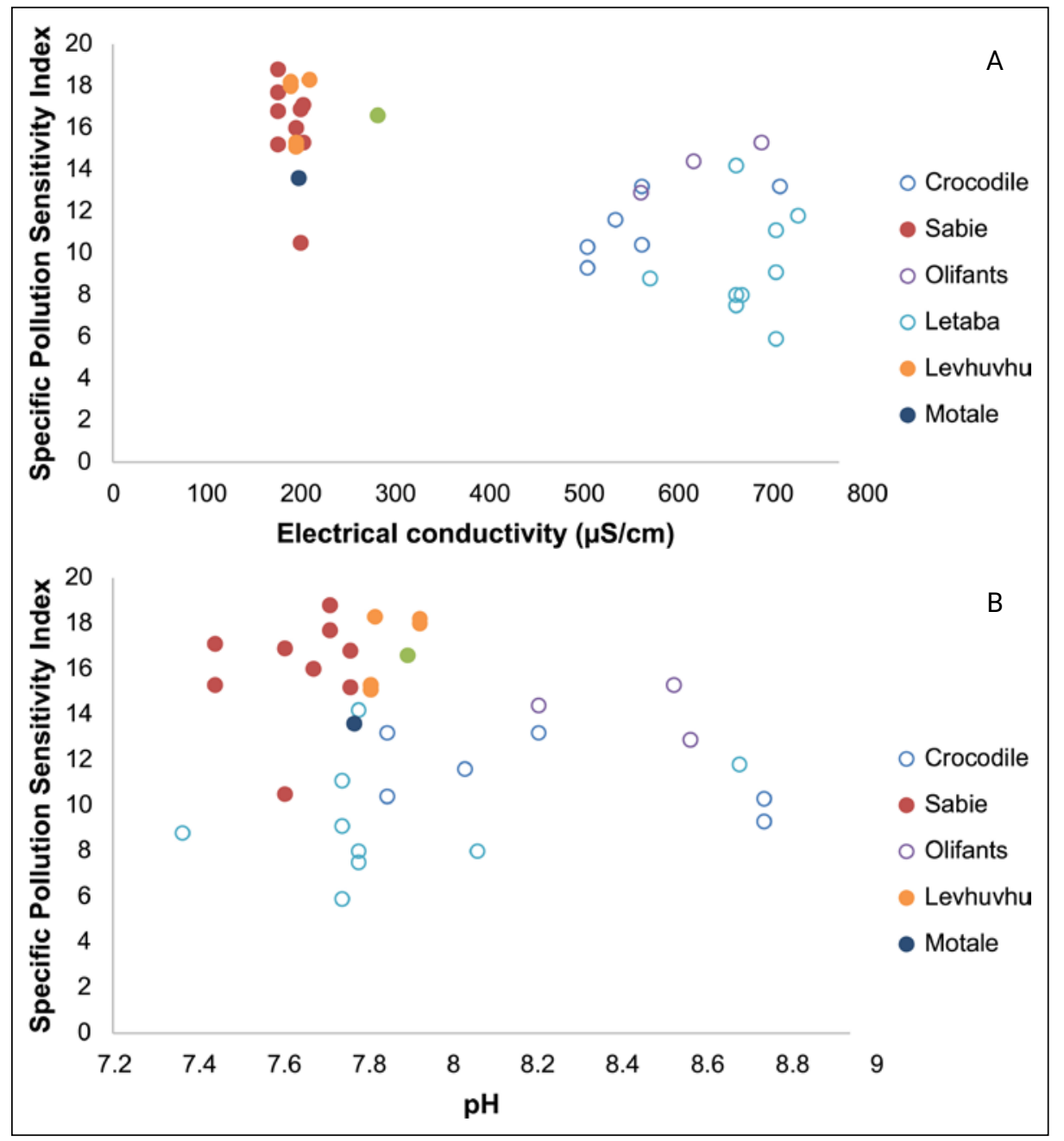

Figure 4. The relationship between SPI and two physicochemical water quality parameters. Open symbols represent rivers with large catchments outside the KNP. Closed represent rivers with relatively small parts of their catchments outside the KNP. In both cases, the darker the symbol, the larger the catchment.

subsequent higher evaporation rates. Our results did not show a significant increase in EC or a change in $\mathrm{pH}$ during the period (Figure 2) of the study, however, diatom based observations, however suggest that the Letaba River has improved in water quality between the two study periods. SPI scores increased from 7.1 in 1983 to 10.4 in 2015 (Table 3), which indicates the negative effects of these past processes.

Other than having a big catchment outside the KNP, the Olifants River is distinguished by its historic water quality problems emanating from agriculture, impoundments, abstraction and mining (Matlou et al. 2017). The observed high EC in the Olifants River may have resulted from sulphates and other pollutant input from mining (O'Keeffe \& Rogers, 2003). We observed high dissolved salt concentrations between 1983 and early 1990s (Figure 2) in the Olifants River, more than five times the salt concentration in the Sabie River during the same period. An evident decrease in salt concentration occurred after the year 2000 (Figure 2). The decrease in salt concentration after 2000 could be due to Foskor mine losing its discharging licence under the new compulsory licencing imposed by the new Water Act of 1998 (McLoughlin et al. 2011). This halted discharge into the Selati River, a tributary of the Olifants River. The year 2000 flood event could also have diluted the salt concentration in the Olifants River. The KNP adopted the Strategic Adaptive Management plan for rivers in the late 1990s. This strategy promoted on-going evaluation and monitoring of the rivers followed by action to be taken against non-compliance (McLoughlin et al. 2011; Pollard et al. 2011). The mitigation strategies applied by freshwater managers seem to have paid off for the Olifants River, considering the decrease in salt concentration after 1990. Additionally, diatom-based observations also suggest that the Olifants River water quality has improved. The SPI score dramatically increased from 7.4 to 14.8 between 1983 and 2015 (see Table 3).

Diatom community structure indicated that there is greater differences between 1983 and 2015 than within the years as the $p$-value does not indicate a significant difference ( $R$ value: 0.587$)$ for all focal rivers (Figure 3 ) irrespective of whether EC and $\mathrm{pH}$ changed or not (Table 2), suggesting broad system changes associated with non-measured water quality parameters. Most, if not all diatom sites sampled in 1983, plotted closer to each other when visualised on the multidimensional scaling (MDS). This is indicative of similarities in diatom community 
structure. Similarly, diatom sample sites investigated in 2015 also ordinated close to each other (Figure 3), meaning that the 2015 diatom community structures are also similar between sites. Diatoms could also be responding to other water quality requirements such as nutrients, which are not accounted for in this study.

Bate et al. (2004) indicated that $\mathrm{pH}$ might not be a good proxy indicator for water quality and this is borne out in the present study. We also did not observe any relationship between SPI and $\mathrm{pH}$ measurements between rivers in 2015 (Figure 4B). However, we observed a significant negative association between SPI score and EC measurements between rivers (Figure 4A). The rivers with large catchments (Olifants, Crocodile and Letaba) generally had high EC and low SPI scores. However, the rivers with smaller catchments (Sabie, Levuvhu and Motale) had low EC and high SPI scores. The observed low EC and high SPI scores suggest that rivers with smaller catchments are in a better water quality status than rivers with large catchments. This observation suggests that protected areas minimise pollution input within their boundaries.

The sub-cosmopolitan concept of diatom distribution suggests that diatom species assemblages and diversity are not determined by geographical location (Round 1991; Smol \& Stoermer 2010), but by water quality parameters (Round et al. 1991). In other words, diatom species thrive in an aquatic ecosystem that satisfies their environmental requirements. For example, diatom species tolerant to elevated nutrients will be abundant in a river system that has excess nitrogen and phosphorous (Hall \& Smol 2010; Stevenson \& Pan 1999). The Olifants River was dominated by Nitzschia frustulum species during 1983 (Table 4), reflecting high levels of pollution and brackish water. However, Rhoicosphenia abbreviata and Epithemia sorex became dominant in 2015, indicating moderate EC and elevated nutrient levels. In 1983 the Letaba River was dominated by Rhopalodia gibba, which was replaced by Cocconeis placentula in 2015 (Table 4). The change in diatom species dominance indicates that the Letaba had high EC waters in 1983 and meso-eutrophic water in 2015 (Table 3). The Sabie River was dominated by
Cymbella kolbei species, which requires water quality at moderate to high EC. C. kolbei was replaced by Encyonema leei (Table 4), commonly occurring in slightly acidic and oligotrophic waters. This species, described from China, has recently been documented from many river systems in South Africa (unpublished data) with no historical records or depiction of it previously being present in the country. There is currently limited knowledge on the occurrence and ecological requirements of this species. Diatom samples collected in different years have reflected the water quality status of the sites at the time of sampling. Additionally, historically-curated diatom samples were also successfully used to hindcast historic water quality status for the KNP rivers.

\section{Conclusion}

The present study showed that EC values have changed over the decades as has the associated diatom community structure, reflected by SPI scores. The $\mathrm{pH}$ did not show a relationship with diatom community structure changes. The Olifants and Letaba rivers showed an improvement in water quality whilst the Sabie River remained approximately the same although the diatom community structure has changed. Additionally, we observed that rivers with small catchment sizes had better water quality conditions compared to rivers with large catchment sizes outside the KNP. The study suggests that diatom assessments might be a useful biomonitoring tool to assess health of rivers over time.

\section{Authors' contributions}

PS (SANParks/North-West University) was responsible for experimental and project design, field work and main author. JT (North-West University) was the supervisor for the project at NWU, contributed to data analysis and acted as second author. DG was the supervisor for the project at the Kruger National Park and contributed to the project design and final text. JB (SANParks) contributed to the statistical analysis and interpretation of the data as well as to the final text.

\section{References}

Barnard, S., Morgenthal, T.L., Stolz, M. \& Venter, A. 2021, 'Impact of land use and flow conditions on the phytoplankton of the Sabie River, South Africa', Bothalia 51(1): 75-92 (hardcopy); 1-18 (online) [this issue].

Bate, G. Smailes, P. \& Adams J., 2004, 'A water quality index for use with diatoms in the assessment of rivers', Water SA 30(4); 493- 497. https://doi.org/10.4314/wsa.v30i4.5101.
Bere, T. \& Tundisi, J.G., 2011, 'Influence of ionic strength and conductivity on benthic diatom communities in a tropical river (Monjolinho), São Carlos-SP, Brazil', Hydrobiologia, 661(1), 261-276. https://doi.org/10.1007/s10750010-0532-0.

Boix, D., García-Berthou, E., Gascón, S., Benejam, L., Tornés, E., Sala, J., Benito, J., Munné, A., Solà, C. and Sabater, S., 2010, 
'Response of community structure to sustained drought in Mediterranean rivers" Journal of Hydrology, 383(1-2), 135146. https://doi.org/10.1016/j.jhydrol.2010.01.014.

Clarke, K.R. \& Warwick, R.M., 2001, Change in marine communities: an approach to statistical analysis and interpretation, $2^{\text {nd }}$ Ed., PRIMER-E: Plymouth, United Kingdom

Dallas, H.F. \& Day, J.A., 2004, The effect of water quality variables on aquatic ecosystems: a review, WRC Report No. T224/04, Water Research Commission, Pretoria, South Africa.

Dalu, T. \& Froneman, P.W., 2016, 'Diatom-based water quality monitoring in southern Africa: challenges and future prospects', Water SA 42(4), 551-558. https://doi. org/10.4314/wsa.v42i4.05.

De la Rey, P.A., Taylor, J.C., Laas, A., van Rensburg, L. \& Vosloo, A., 2004, 'Determining the possible application value of diatoms as indicators of general water quality: A comparison with SASS 5', Water SA 30(3), 325-329. https://doi.org/10.4314/wsa.v30i3.5080.

DWA (Department of Water Affairs), 2013, National Water Resource Strategy: Water for an equitable and sustainable future, 2nd edition. Department of Water Affairs and Forestry, Pretoria, South Africa.

Eloranta, P. \& Soininen, J., 2002, 'Ecological status of some Finnish rivers evaluated using benthic diatom communities', Journal of Applied Phycology 14, 1-7. https://doi. org/10.1023/A:1015275723489.

Hall, R.I., \& Smol, J.P., 2010, 'Diatoms as indicators of lake eutrophication'. In: E.F. Stoermer \& J.P. Smol (eds.) The Diatoms: Applications for the Environmental and Earth Sciences. pp. 122-151. Cambridge University Press, Cambridge. https://doi.org/10.1017/CBO9780511763175.008.

Harding, W.R. \& Taylor, J.C., 2011, The South African Diatom Index $(S A D I)$ - a preliminary index for indicating water quality in rivers and streams in southern Africa, WRC Report No. 1707/1/11, Water Research Commission, Pretoria, South Africa.

Harding, W.R. \& Taylor, J.C., 2014, 'Diatoms as indicators of historical water quality: A comparison of samples taken in the Wemmershoek catchment (Western Province, South Africa) in 1960 and 2008', Water SA 40(4), 601-603. https://doi.org/10.4314/wsa.v40i4.4.

Harding, W.R., Archibald, C.G.M., Taylor, J.C. \& Mundree, S., 2004, The South African diatom collection: An appraisal and overview of needs and opportunities, WRC Report No. T242/04, Water Research Commission, Pretoria, South Africa.

Harding, W.R., Archibald, C.G.M. \& Taylor, J.C., 2005, 'The relevance of diatoms for water quality assessment in South Africa: A position paper', Water SA 31, 41-45. https://doi. org/10.4314/wsa.v31i1.5119.

Hart, R.C, 2006, 'Food web (bio-)manipulation of South African reservoirs - viable eutrophication management prospect or illusory pipe dream? A reflective commentary and position paper', Water SA 32, 567-589. https://doi. org/10.4314/wsa.v32i4.5281.

Lecointe, C., Coste, M. \& Prygiel, J., 1993, “"Omnidia”: Software for taxonomy, calculation of diatom indices and inventories management', Hydrobiologia 269/270, 509513. https://doi.org/10.1007/BF00028048.

Mangadze, T., Bere, T., \& Mwedzi, T., 2016, 'Choice of biota in stream assessment and monitoring programs in tropi- cal streams: A comparison of diatoms, macroinvertebrates and fish', Ecological indicators 63, 128-143. https://doi. org/10.1016/j.ecolind.2015.11.029.

Mangadze, T., Wasserman, R.J. and Dalu, T., 2017, 'Use of diatom communities as indicators of conductivity and ionic composition in a small Austral temperate river system', Water, Air, \& Soil Pollution, 228, 428. https://doi. org/10.1007/s11270-017-3610-3.

Matlou, K., Addo-bediako, A. \& Jooste, A., 2017, 'Benthic macroinvertebrate assemblage along a pollution gradient in the Steelpoort River, Olifants River System', African Entomology 2, 445. https://doi.org/10.4001/003.025.0445.

McLoughlin, CA., Deacon, A., Sithole, H. \& Gyedu-Ababio, T., 2011, 'History, rationale, and lessons learned: Thresholds of potential concern in Kruger National Park river adaptive management'; Koedoe 53, 75-96. https://doi. org/10.4102/koedoe.v53i2.996.

O'Keeffe, J.H. \& Davies, B.R., 1991, 'Conservation and management of the rivers of the Kruger National Park: Suggested methods for calculating instream flow needs', Aquatic Conservation: Marine and Freshwater Ecosystems 1, 1-17. https://doi.org/10.1002/aqc.3270010105.

O'Keeffe, J. \& Rogers K.H., 2003, 'Heterogeneity and Management of the Lowveld Rivers'. In: J.T. du Toit, K.H. Rogers, \& H.C. Biggs, (eds.), The Kruger experience: ecology and management of savanna heterogeneity, pp. 447-468, Island press, South Africa.

O'Keeffe , J.H., \& Uys, M., 1998, 'Invertebrate diversity in natural and modified perennial and temporary flow regimes'. In: A.J. McComb and J.A. Davis (eds.), Wetlands for the future, pp. 173-184, Gleneagles Publishing, Adelaide, Australia.

Pollard, S. \& du Toit D., 2011, Towards the sustainability of freshwater systems in South Africa; WRC Report No. 477/10, Water Research Commission, Pretoria, South Africa.

Pollard, S., du Toit, D., \& Biggs, H., 2011, 'River management under transformation: The emergence of strategic adaptive management of river systems in the Kruger National Park', Koedoe 53, 1-14. https://doi.org/10.4102/koedoe. v53i2.1011.

Riddell, E., Pollard, S., Mallory, S \& Sawunyama, T., 2013, 'A methodology for historical assessment of compliance with environmental water allocations: Lessons from the Crocodile (East) River, South Africa', Hydrological Sciences Journal 59(3-4), 831-843. https://doi.org/10.1080/02626 667.2013 .853123$.

Round, F.E., 1991, 'Diatoms in river water-monitoring studies', Journal of Applied Phycology 3, 129-145. https://doi. org/10.1007/BF00003695.

Roux, D.J. \& Nel, J.L, 2012, 'Freshwater conservation planning South Africa: Milestones to date and catalysts for implementation', Water SA 39, 151-163. https://doi. org/10.4314/wsa.v39i1.15.

Rott, E., 1991, 'Methodological aspects and perspectives in the use of periphyton for monitoring and protecting rivers'. In: B.A. Whitton,, E. Rott, \& D. Friedrich (eds) Use of algae for monitoring rivers, pp. 9-16. Intitut fur Botanik, Universität Innsbruck.

Smol, J.P. \& Stoermer, E.F., 2010, The diatoms: Applications for the environmental and earth sciences, 2nd Edition, Cambridge University Press. pp. 3-15. 
Stevenson, R.J. \& Pan, Y., 1999, 'Assessing environmental conditions in rivers and streams with diatoms'. In: E.F. Stoermer \& J.P Smol (eds.), The Diatoms: Applications for the Environmental and Earth Sciences. pp. 11-40. Cambridge University Press, Cambridge.

Swemmer, A.M., Bond, W.J., Donaldson J., Hempson, G.P., Malherbe, J., Smit, I.P.J., 2018, The ecology of drought - a workshop report. South African Journal of Science 114(9/10), 1-3. https://doi.org/10.17159/sajs.2018/5098.

Taylor, J.C., Harding, W.R. \& Archibald, C.G.M., 2007a, A methods Manual for the Collection, Preparation and Analysis of Diatom Samples Version 1.0; WRC Report No. TT 281/07, Water Research Commission, Pretoria, South Africa.

Taylor, J.C., Harding, W.R. \& Archibald C.G.M., 2007b, An illustrated Guide to Some Common Diatom Species from South Africa; WRC Report No. TT 282/07, Water Research Commission, Pretoria, South Africa.
Tsu-Chuan, L., \& Clark C. K., 2018, 'Assessing Eutrophication Potential of a Freshwater Lake by relating its bioproductivity and biodiversity: A case study of Lake Wilson on Central Oahu, Hawaii'; Water Journal 10, 296. https://doi. org/10.3390/w10030296.

Venter, F.J., \& Deacon, A.R., 1995, 'Managing rivers for conservation and ecotourism in Kruger National Park'. Water Science and Technology 32, 227-233. https://doi. org/10.1016/0273-1223(95)00667-2.

Wepener, V., 2008, 'Application of active biomonitoring within an integrated water resources management framework in South Africa', South African Journal of Science 104, $367-372$.

Zheng, Z., Xu, Y., Wang, J., Li, Y. and Gu, B., 2019, 'Environmental stress and eutrophication in freshwater wetlands: evidence from carbon and nitrogen stable isotopes in cattail (Typha domingensis Pers.)', Ecological Processes, 8(1), 31. https://doi.org/10.1186/s13717-019-0186-4. 